\title{
Socioenvironmental sustainability actions in hotel management
}

\author{
Ações de sustentabilidade socioambiental na hotelaria
}

Anderson Soares Lopes, Paulo Santos de Almeida

\begin{abstract}
The present study contemplates an exploratory research of a qualitative nature in articles and sites, mainly associated to the tourism and Socioenvironmental sustainability aspects. Therefore, the main objective of this research is to identify and evaluate the actions of responsibility developed in the Socioenvironmental sphere by the employees of the hotel sector. In the midst of these considerations, it was used as a reference model Atlantica Hotels International and it is presented a diagnostic analysis in order to demonstrate through an applied research with the Training Manager and the organization's website in order to develop actions in the social and environmental context. In this way, there are opportunities to improve the environment which the lodging environment is located, aiming to preserve environmental resources, and to fight possible damages that may be caused by tourism, among this violence against children and adolescents.
\end{abstract}

KEYWORDS: Tourism; Hospitality; Socioenvironmental Sustainability; Sustainable Cities; Atlantica Hotels International.

\section{RESUMO}

O presente estudo contempla pesquisa exploratória de caráter qualitativo em artigos e sites, sobretudo, associadas as vertentes do turismo e da sustentabilidade socioambiental. Por isso o principal objetivo desta pesquisa é identificar e avaliar as ações de responsabilidade desenvolvidas na esfera socioambiental pelos colaboradores do setor hoteleiro. Em meio a estas considerações, utilizou-se como modelo referencial a Atlantica Hotels International e apresenta-se análise diagnóstica no intuito de demonstrar por meio de pesquisa aplicada com o Gestor de Treinamento e site desta organização formas de desenvolver ações no contexto social e ambiental. Desta maneira registram-se oportunidades para melhora do entorno em que o meio de hospedagem encontra-se inserido, com vistas a preservação dos recursos ambientais, e a combater possíveis danos que possam vir a ser causados pela atividade turística, dentre estes violências contra crianças e adolescentes.

PALAVRAS-CHAVE: Turismo; Hotelaria; Sustentabilidade Socioambiental; Cidades Sustentáveis; Atlantica Hotels International. 


\section{Introduction}

This article is a result of the research about the activity and the hosting role models in Brazil and it intends to discuss the impact of these developments on the environment where they are installed. Therefore, for the purposes of this research it was considered the guidelines found in the context of sustainability, especially in the environmental and social perspective. In this context Carter et al. (2015) points out that through tourism development in certain localities there is: job creation, poverty reduction, and thus, tourism fulfills its social function in the parameters of sustainability.

However, among the primary considerations of the research it was considered that to relate the activity of lodging facilities and aspects of sustainability it is viewed that this tends to cover different perspectives, and this relation is worthy of further investigation, such as economic sustainability, sometimes related to applied sciences, and the study fields of administration and management. Before this reality Carter et al. (2015) observes that the sustainable qualification is present in different sectors of economy and tourism along the same lines of thought, it is due to government pressure and different stakeholders in the sector.

Therefore, it has been considered that the perspective of sustainability through customs and practices need to be present throughout the tourism activity (CARTER et al., 2015). This perspective also needs por act the same way in other fields of activity and science.

Within context it should be emphasized that most of the researchers when they develop their investigations intend to demonstrate the relationship or the intertwining of science and its applicability in everyday society. This and other questions already occur a long time, in a specific case Stokes (2005) reveals the inquiries have already occurred a long time ago in the United States about the permanence or otherwise of investments in research in the period after the Cold War.

Through this scenario concepts and studies have been developed in this period on the applicability of science in its different levels and it was also demonstrated that there is a need to continue to move forward on these issues, because investments in science and technology in several areas of study are critical for the development of a nation. By raising the debate on the relation are between science, the State and the power, Zioni (2005) considers that the progress of the knowledge goes along with capitalism, and this occurs by different means, among which it is located the reason and scientific method.

Among these worthy areas of development and research, in order to advance different aspects, it has been located sustainability issues. Therefore, to relate the issue of sustainability the studies by Souza et al. (2012) and Diego et al. (2011) were analyzed once they highlight briefly the influence of man facing the changes in dynamic society and the natural environment since the Industrial Revolution. 
This has been causing negative consequences of high proportions, which highlights the depletion of natural resources and the generation of bland pollution (ZIONI, 2005). Either directly or indirectly it interferes with the habits and customs of human life, and it affects mostly the health, and the ecosystem has also been depreciated, causing damage that is sometimes irreversible.

Among other consequences that occurred after the Industrial Revolution stands out, according to Souza et al. (2012), the development of the technology which has contributed to increased trading, improved business productivity, the advancement in the media and consequently the rapidly expand in the globalization process.

According to Zioni (2005) throughout history there has been a number of changes which sometimes interfere with the way of thinking, acting, communication and participation of human beings in their daily lives, these events generated a new organization of society and the desire for products even little known ones in certain regions of the world, among them, it has been observed the Renaissance, the Scientific Revolution, the Protestant Reformation and overseas expansion.

Stokes (2005) says that the Scientific Revolution in the seventeenth century and the Industrial Revolution in the nineteenth century served as actions that decisively pushed for the creation of the modern world, in which it highlights the advance of the globalization phenomenon. This later phenomenon led to the organization of the countries by means of economic blocs through bilateral agreements as an attempt to reduce trade barriers and ease free trade.

In the world it is visualized in different parts of the planet examples of this integration, among them stands out the APEC (Economic Cooperation in Asia and the Pacific), which seeks sustainable economic growth in the AsiaPacific countries to encourage economic integration and economic and technical cooperation (APEC, 2015).

In South America this union is represented by the Southern Common Market - MERCOSUL, which seeks to establish a trade policy and common external tariff, the free movement of goods and the wide coordination of laws and policies among member countries, this economic bloc appeared in March $26^{\text {th }}$, 1991 from the Treaty of Asuncion, initially composed of countries like Brazil, Uruguay, Argentina and Paraguay, in the following years they were associated with Bolivia, Chile, Peru, Colombia, Ecuador, Guyana, Suriname and Venezuela ( MERCOSUL, 2015).

By this context it appears that among other reasons for the sharp advance accelerated the globalization process there is the apparent need for production flow for developed countries. According to Souza et al. (2012) the process of globalization allied with technological advances have contributed to expanding trade worldwide. But it is common to see responses previously developed regarding this process to signal the need for greater integration among the different locations of the planet and the improvement of information exchange between developed and underdeveloped countries. 
Mello et al. (2012) states that these and other facts eventually influenced and triggered the increase of business competitiveness worldwide. For purposes of this research it is reported since now that this has also occurred in the traditional tourist and hotel industry, after all, these two sectors are also inserted in the consumer market.

Even without seeking to make major questions about the process of globalization and the advances made in technology and other sectors, it raises the debate about the environmental, social and cultural life of man, that because of the need to increase economic rates, the pursuit for profit, these areas are sometimes relegated to oblivion and thus it is possible to visualize the environmental degradation scenario, and the exclusion and exploitation of man in his routine life. Zion (2005) raises the debate on the progress made with modernity on the problems generated reveals that it is necessary to review the entire social context about society.

When considering social indicators, there is the search for assessing the parameters related to the welfare of populations, as this mobilizes governments, for example, Prime Minister David Cameron and President Nicolas Sarkozy (ABBOTT; WALLACE, 2011). Among the main consequences listed by this reality stands out in France the creation of the Commission on the measurement of economic performance and social progress, which seeks to carry out a focused welfare approach of the population when considering the economic outlook, and the environmental and social sustainability (COMMISSION ON THE MEASUREMENT OF ECONOMIC PERFORMANCE AND SOCIAL PROGRESS, 2015). In this context, in order to consider the issue of the welfare of a population Abbott and Wallace (2011) advocate the use of a complete model that includes the satisfaction of the people related to labor, family and housing issues.

So theres is a clear need the clear need to rethink the current development model, and also it is necessary to seek viable alternatives to take account of the different stakeholders in this process, including the man himself. But the actions taken today in favor of the environment and social responsibility are minimal compared to the damages. Before that, Carter et al. (2015) points out that even with its limitations tourism has a humanitarian role.

Thus for Souza et al. (2012) from the Brundtland Report came the concept of sustainable development. This aims to associate issues related to the improvement in the economy and the preservation (WWF Brazil, 2014). This model is presented as an option for companies and organizations, market limits emphasize the desire to reduce the impact on man and nature.

So to raise the idea of sustainability, it is revealed that there is a need to set the location, date and the object of research, in order to ease analysis and prevent further interference in the investigation process. According to Souza et al. (2012) in the areas of sustainability They have to have a good screening of its methods. Therefore, it emphasizes that the research study object the actions developed in social and environmental perspective by employees of lodging facilities. 
The research problem then, investigates what the effectiveness of social and environmental responsibility of a group activity for the development of a city making it sustainable, meaning the environment in which these companies and organizations are.

The hypotheses of the research, on the other hand, would be, employees of the hotels managed by the company analyzed develop practices in order to inhibit sexual tourism and this tends to favor the environment of these businesses, as this prevents the development of violations and child and adolescent abuse in vicinity of these developments, and the actions developed in the Socioenvironmental context tend to reflect positively on the organization's image, especially to add value and loyalty among its guests and visitors.

Thereat, the present research is justified because the authors understand the need for better analysis regarding the actions undertaken by the lodging facilities within the territorial limits of Brazil especially in social and environmental perspective, which composes and is a part of the sustainability universe.

Therefore, the overall objective of the research is to identify the responsible actions developed in the environmental sphere by employees of the hotels managed by Atlantica Hotels International, assessing whether these tend to benefit the environment of the enterprise and finally, making sure that this is reflected in the maintenance of good image of the organization. The specific objectives of this study are:

1.Identify environmental initiatives developed by the hotels managed by Atlantica Hotels International;

2.Evaluate through a questionnaire with a representative of the hotel management how the actions developed by these developments in the context of sustainability tend to benefit its surroundings;

3.Verify if the actions developed by the company's employees analyzed in an attempt to inhibit sex tourism tend to benefit the environment of the enterprise;

Thus, to investigate the objectives of this research, it was aimed to promote good practice and expose good deeds from the perspective of sustainability, in order to add knowledge to the national hosting industry and encourage other organizations to engage in the development of these. Therefore, contributing to the emergence of new possibilities and instigating the enterprises operating in the hosting industry to adopt new practices with a view to considering all those interested in the perfect operation of these enterprises. 


\section{Methodology}

In the methodological procedures of this study, it is revealed that it has have been developed research articles and researches at national and international levels, and organizations websites and its activities are located in the set of environment initiatives practice of sustainability in different knowledge fields.

The authors sought to privilege those studies which presented in their themes the context of sustainability, especially in social and environmental perspective, but it was observed that most of the articles or materials located contemplated only the aspects of sustainability in an environmental perspective.

It has been considered that this research progresses and serves as a study reference for further investigations to seek among other possible features, interlacing knowledge at the national level about these practices to learn willing internationally, especially to investigate the different dimensions of sustainability.

Toward the same perspective they sought to trace further considerations about the positive and negative impacts caused directly and indirectly by means of accommodation. To carry out a study along these lines Koga and Wada (2013) aim to discuss the role and influence of these projects with multiple stakeholders in this scenario.

Therefore, this study will seek to make a survey about the interaction between employees of the analyzed company and its actions in the social and environmental context, wherefore it will mean analyzing the initiatives of the hotels managed by Atlantica Hotels International with entities that work and develop their actions for a more egalitarian society. Thus it is considered that there is a consensus that a new form of development that is less exclusive present is needed (WWF Brazil, 2014).

So we have tried to consider the parameters of sustainable development applied the perspective of the hotel business. After all these days it is considered that regardless of size, size and target audience, an active project in the hosting industry needs to be in constant harmony with the environment in which it is. Continuing the article, it seeks to examine whether the actions taken by employees of the hotels managed by Atlantica Hotels International tend to avoid the development of violations, better known as abuse of children and adolescents in the vicinity of these developments.

Because of the hotels placed in the context of the tourism market, this article will look consider ABNT NBR 15401: 2006, which is also presented in the study by Matos and Costa (2012), in which contributions stands out and seeks to develop the boundaries of sustainability standards for tourism development in Brazil.

Consequently, this study enforces a questionnaire with Mr. Paulo Lima, the Atlantica Hotels International Training Manager, professional who presents throughout his career a collaborative history in the corporate education environment for multinational companies active in the territorial limits Brazil like Philip Morris, Antarctica and Roche (LIMA, 2014). 
Thereby, with this perspective we tried to consider the social and environmental areas of sustainability, understanding that this method would be the best way to achieve the research objectives, and also by the restlessness of one of the researchers to visualize that the hotel and lodging industry develop activities that tend to go beyond those related to the fact of hosting and accommodating people.

Among the final considerations of the article, it considers at this stage the study, the results on websites, books and periodicals and evaluate the results of the research that investigates the measures and actions of hosting means analyzed in order to add and contribute with its surroundings, not forgetting to assess and make further consideration that the authors consider it to be a vital importance to the investigation.

\section{Hotel activity impact in the cities}

Before a host resource to settle on a destination it is necessary to ensure the minimal conditions for this activity to succeed, it is the reason why it is so essential to have the minimum of basic infrastructure in the environment of a tourist town. For Koga and Wada (2013) the existence of the hosting industry in a destination is very important to the development of the tourism activity.

In this context we consider the process of urbanization, which according Alusi et al. (2011) this perspective constitutes a complex process, since it involves the projection, management and use of space. This becomes essential because sometimes cases of tourist complexes are visualized in places where the power supply, water and sewage are not a constant reality.

Carter et al. (2015) points out that part of the initiatives in Cambodia, in order to develop tourism especially with the sustainability parameters, is stuck in the apparent lack of infrastructure location. In Brazil before the international sporting events the country is hosting it was verified that this led the government in its different spheres to seek ways to improve the infrastructure offered in the environment of Brazilian cities (SAULE JUNIOR, 2015).

The prospect of infrastructure becomes a key element to companies and organizations, among them, the lodging facilities of a destination may succeed. To Alusi et al. (2001) in order to develop sustainable cities, activities that respect the environment and society in a locality, the Bank sought partnerships in order to evaluate the economic viability of eco cities or sustainable destinations.

In this perspective Alusi et al. (2011) notes that these cities need to gather characteristics associated with the search for a clean energy generation; transport system that facilitates the displacement of people through hiking, bicycle use and the use of public transport; reduction of waste generated, and finally, the use of local building materials and respecting the environment. 
For example, it is found in certain tourist destinations, that it is common to drop the energy or water supply in part of the day, and this could lead the companies in this locality the losses on a large scale, depending of course on how this organization is prepared to administer these cases. In the project of the World Bank, Alusi et al. (2001) shows that it seeks to contemplate parameters of economic and ecological sustainability.

To better expose this case Alusi et al. (2011) links parameters in economic and population growth shows that $60 \%$ to $80 \%$ of the world's energy production is used by the cities. So these urban interventions are related to urban restructuring works, on the other hand, they represent high costs to be paid by the local population in the form of taxes, so is because of the spatial reorganization or the increase in charges that these works are causing social and environmental impacts (SAULE JUNIOR, 2015).

In this perspective there is an increasing scenario of urban interventions in emerging countries (SAULE JUNIOR, 2015), as it is the case of Brazil. It is emphasized on this process must consider standards that respect the different stakeholders of the urban environment. According to Mello et al. (2012) in Brazil, the social and environmental context, which is presented a huge gap that demonstrates the real situation of the country.

This perspective in the context of tourism and hospitality is very important, especially when considering the inclusion of the local community in the daily activities of the project, as Carter et al. (2015) states, these activities provide significant benefits even in cases of people with low professional qualifications. This reality is a way to call the attention against indifference and ensure the security of enterprise stakeholders.

The guidelines of the rule ABNT NBR 15401 (2006) it is observed the suggestion that the means of hosting use people from the local community to administer and manage the enterprise, but there is one limitation, in order to accomplish a good management of active enterprises in the sector of tourism and lodging, it is necessary to gather a set of knowledge, skills and attitudes, and this is acquired over a career.

After examining the considerations, the public and private managers need to observe what the real consequences of this activity are, because we understand that this fact will generate positive and negative impacts in the region. For Peres Jr. and Rezende (2011) tourism and its associated industries need to have a proper planning and implementation, which intend to minimize violence to natural and social aspects of receptive centers.

Therefore, local managers need to formulate actions to plan and develop tourism to a destination, and be willing to follow the dynamics of the tourism system in order to encourage participation. For Burgui (2013) the tourism is usually combined with other sectors.

In this perspective, the standard NBR 15401 (2006) establishes that lodging facilities are organizations which among its main activities there is the provision of accommodation (MATOS; COSTA, 2012). But these developments in their daily operational routine demonstrate the ability to 
develop other features for more complex times and are also in accordance with the needs and consumption patterns of its guests and visitors.

In the study done by Koga and Wada (2013) it was analyzed the relationship lodging facilities of Vila do Abraao (RJ, Brazil) and its stakeholders and it was presented that part of these projects aims financial return, and that in this region there is a strong relationship conflict, also represented by the disunity among the projects due to high competition.

Even though the dynamics of these companies interferes in this tourist destination, the benefits related to tourism activity could be better reflected if there was a better integration between public and private power, as well as if there was a friendlier relationship between the companies active in the tourism sector in the region (KOGA; WADA, 2013).

In the study of Koga and Wada (2013) they state that among other strategies it is shown the need for an extensive coordination among organizations working in this destination in order to obtain greater benefits compared to the suppliers, seeking to improve basic services for the provision of water, electricity and sewage. Finally, it was also included in this agenda the improvement or the search for better maintenance of equipment for tourism in order to ease access to visitors.

In this case, Koga and Wada (2013) reveal the lack of coordination among these organizations in the private sector which is also presented in public places and they should seek to develop ways to organize the sites and to receive its visitors, there is an obvious lack of guidelines that should promote the feedback to the quality control of services offered.

Even with the intention to analyze the impacts related to activities of lodging facilities, Mello et al. (2012) reveals that in Brazil this is a recent task, at first in Brazil there was the attention associated with degradation of natural resources, mainly due to lack of a standard to be followed. For Diego et al. (2001) in the hotel sector this occurs in a more controlled way.

Same Burgui (2013) points out numerous impacts listed which came from tourism exploitation and its related sectors, above it all, the author considers the activity of lodging facilities in Cayo Santa Maria in Cuba an interference with the local landscape and in social relations the resident population and environmental dynamics of the region.

The impacts listed by Burgui (2013) are shown through building hosting projects of large dimensions in small territories, extra-hotel oversupply with the proposed construction of an international marina with capacity for 460 moorings and product integration to control insects that sometimes affects the local flora and fauna.

In addition, there is also the impact of water plants and changing marine landscape due to sewage and effluents discharged by hotels and resorts, inadequate treatment of waste and environmental resources, and finally, introducing species of different flora and fauna for decoration of lodging facilities in spaces such as gardens, which alters the vegetation and the local ecosystem (BURGUI, 2013). 
In this context Diego et. al. (2011) shows that negative impacts related to these projects sometimes are represented by the rampant use of natural resources and generation of waste. However, Mello et al. (2012) reveals that today we try to control all possible forms of pollution.

Even with these considerations it is understood that the hosting industry tends to also generate positive impacts associated with aspects of sustainability and hospitality, this will depend on the way in which its services are designed, planned and formulated, in other words, the way the management of resources and services is made.

Among other reasons for this finding lies the fact that, as shown by Diego et al. (2011), the tourism and hospitality sectors are largely related to local features where they are. In this perspective Burgui (2013) adds that the tourism activity relates to the resources at their surroundings and needs the landscape directly.

After these considerations we intend to demonstrate that issues related to social perspective and the environmental preservation of a region are contemplated by companies in the tourism industry and modern hotel by means of internal and external actions undertaken by employees and partners of these organizations in their daily routine service.

\section{The sustainable development and the hotel management}

When providing services in the hotel industry we consider in this context the five senses: hearing, smell, taste, sight and touch, this occurs with the main purpose of providing the customer satisfaction. In this context and in the pursuit of investigations into the tourism theme and its branches or set of associated issues, Dolnicar et al. (2012) reveals that the UK has been developing studies about a number of aspects, among them a set of psychological dimensions and also associated to the well-being of the traveler, willing to demonstrate the relationship between tourism and leisure in people's lives (MCCABE; JOHNSON, 2013).

Aspects related to the expectations of visitors to an active organization in the sectors of tourism and accommodation sometimes becomes a difficult task to perform. This also occurs in the development of researches in the sectors of tourism and hospitality as points out Sirgy (2010) and Uysal, Perdue \& Sirgy (2012) about the studies on the tourist behavior, because for these authors a small number of theories that address different topics related to better quality of life and well-being during the trip are also limited (MCCABE; JOHNSON, 2013).

Since that for these consumers the details are important, it is also considered that the subject of satisfaction is broader, beyond issues related to motivation of people to travel. For Peres Jr. e Rezende (2011) it has become common to see companies in the tourism and accommodation sector that try to adapt its operational routine issues of sustainability in social and environmental sphere. 
According to the Economic Vision Statement of the APEC Leaders (1993) to elaborate the principles about the integration of economy and sustainable development it is emphasized that the environment has to provide better benefits to human life and to be improved when it seeks to protect natural resources, among them water and air, and develops, in a balanced manner, a good management of energy and renewable resources to ensure sustainable development (APEC, 2015).

In the hotel business, guest satisfaction involves tangible and intangible aspects. In this context Peres Jr. and Rezende (2011) highlight hotel companies which develop environmental initiatives in order to minimize the impacts caused by its activities, as the hotel group Marriott, Hilton and Starwood. Therefore, social and environmental initiatives in the hotel sector are important because concerns about the satisfaction of stakeholders in this sector ranges from the quality of visitation, receiving people, how to accommodate them, so they will be available the services, infrastructure characteristics and enterprise architecture, its location and its interaction with the environment.

According to Diego et al. (2011) the attributes of the receptive center or destination city are key aspects for the development of tourism and the hospitality of a region. Through receptive quality and service of a means of hosting a tourist can see the venture where he is hosted in the daily routine aspects associated with standards of hospitality and sustainability.

In this context highlighting the perspective of sustainable development, Diego et al. (2011) emphasizes the importance of creating a sustainability committee on the environment of a host resource, such as the Hyath Earth deployed at the Grand Hyatt São Paulo that in the development of its functions creates initiatives as an attempt to disseminate knowledge on environmental context.

According Diego et al. (2011) the actions developed by Hyath Earth sustainability committee consider the efforts to reduce water and energy consumption, the better use of the project activities in the provision of goods and services, maximizing the activities related to selective collection, minimizing production waste and carbon dioxide.

Before that, it has been demonstrated that this research seeks to cover issues related to the way of acting of the hotels and their activities associated with the parameters of social and environmental responsibility, this activity when it is not developed proactively by industry entrepreneurs sometimes, has to be made in order to respond to compliance and government standards accompanied by state regulators.

The survey conducted by Matos and Costa (2012) presents as a reference model to ABNT NBR 15401 (2006) that within its main purposes establish sustainable development parameters better located in the tourist industry, particularly we verify that from this conditions are established and they tend to serve thresholds to be followed for the lodging facilities to plan their routine activities. 
Through the establishment of this standard the Commission for Sustainable Tourism Study (2006) it is expected to develop some ways to enable the decrease of the emission of waste, optimize the use of water and other renewable resources, the search for the preservation of natural areas, the search for the best use of energy, and also the financial viability of the activities and services offered in small and medium enterprises of the hosting industry that adhere to these standards (ABNT NBR 15401, 2006).

On the other hand, in a social context we expect to develop ways to improve the welfare for employees, safety and visitor satisfaction, to grant formal employment and improve the incomes for the resident population, the preservation of cultural patterns, and the best professional skills development of the resident population (ABNT NBR 15401, 2006).

The standard NBR 15401 (2006) emphasizes the importance of including the resident community in the productive chain of tourism, in order to fight against the prostitution of children and adolescents, and sex tourism. This perspective considers aspects associated with the time available for residents to participate in these activities and also the records made by the resident community about their satisfaction and complaints regarding the carried out activities, or how it is developing the interaction and management of relations between travelers and hosts. Therefore, it becomes primordial the set of actions related to the association, so the mean of hosting encourages local production and stimulates economic activities with quality and sustainability in the tourist hub.

In this regard, it is highlighted that according to NBR 15401 (2006) of staff remuneration cannot be different taking into account gender or gender distinction. This standard also establishes that half of the workforce related to the routine activities of the enterprise has to be from the local communities (ABNT NBR 15401, 2006).

So it was sought to promote local activities involving the routine of daily operations of the means of accommodation, the NBR 15401 (2006) also urges the development of complementary activities, such as the search for the trade development, labor, and traditional and new opportunities among these there is the encouragement of the crafts and typical products of the region.

Alusi et al. (2011) highlights the pioneering initiatives such as the pursuit of China Construction Ministry in 2008 to develop a classification system that includes environmental standards and can generate clean energy in so-called Green Buildings. This reality, of course, with its proper precautions could be perfectly suited to the reality of the hotel sector, sometimes thinking of green hotels socially and environmentally responsible.

Alusi et al. (2011) reveals that the adoption of these models presents a proposal to reduce pollution and harmful emissions to the health of people as the greenhouse effect. By this stage it appears that there is an extensive field of activity. Among these, it is observed that these initiatives are adopted in different spheres of public and private power, such as in 1997 at the APEC meeting in Canada APEC sought to provoke debates for guidelines related to 
sustainability in the marine environment and the adoption and development of clean technologies and fostering sustainable city (APEC, 2015).

In this context, for example, Alusi et al. (2011) shows that China's government expects to decrease about $65 \%$ of the energy use of buildings, and the European Union submitted a proposal for the use of public buildings using energy almost nonexistent.

Before the awareness of different sectors in the global context, through the establishment of state standards and initiatives related to companies or organizations, it is observed that about the Socioenvironmental context in Brazil, the country still occupies a peripheral position regarding the search for sustainable initiatives in different sectors, among them tourism and accommodation sectors. However, there has been come isolated actions that due to the size and size of the organization has established itself as a model to be followed, so this view will be used as a reference model to Atlantica Hotels International.

\section{The research}

When designing and developing this article it was sought to conduct an interview with Mr. Paulo Lima, psychologist and Atlantica Hotels International Training Manager. This company is an independent multi-brand hotel manager privately held, with more than 80 hotels in Brazil, adding more than 13.000 rooms (LIMA, 2014).

Among the main activities carried out by this company, it presents the hotel and hospitality (ATLANTICA HOTELS INTERNATIONAL, 2015) in this context, it is demonstrated that the organization understands that its main business involves the art of welcoming people in their activities.

So Lima (2014) reveals that among all the tasks and assignments it is necessary to search for forming a culture of service that addresses issues facing the satisfaction of the guests and visitors of these hotels. So the attributes about the vast guest satisfaction need to be present in all the hotels of the organization in the different regions of Brazil.

By the intention allied to the context of service and customer and visitors satisfaction, this organization presents the development of educational activities, the context linked to training people in order to provide to their employees more than 70 courses in different departments of the media hosting, whether in operational areas or administrative sectors, and, in addition, afford partnerships with educational institutions such as the National Service for Commercial Learning - SENAC (LIMA, 2014).

Through the data exposed by Lima (2014) and to better clarify the corporate actions by the company researched done in order to empower its employees prepared the table 1 - training Actions and collaborators developed by qualification by Atlantica Hotels International. 
Table 1: Actions of training and qualification of staff developed by Atlantica Hotels International.

Quadro 1: Ações de treinamento e capacitação de pessoal desenvolvido pela Atlantica Hotels International.

\begin{tabular}{|l|l|}
\hline \multicolumn{1}{|c|}{ Action } & \multicolumn{1}{c|}{ Tool } \\
\hline Training and qualification & $\begin{array}{l}\text { Availability of more than 70 courses across all disciplines to } \\
\text { operational and administrative employees } \\
\text { Maintenance of partnerships with recognized bodies, such } \\
\text { as the SENAC }\end{array}$ \\
\hline Career incentives & $\begin{array}{l}\text { Corporate University } \\
\text { Talent management program } \\
\text { Plan of jobs and salaries } \\
\text { Performance incentives } \\
\text { Trainee Program } \\
\text { Engagement program }\end{array}$ \\
\hline Relevant items & $\begin{array}{l}\text { Train and develop the culture of service dedicated to } \\
\text { excellence and guest satisfaction }\end{array}$ \\
\hline
\end{tabular}

Source: Lima (2014). Fonte: Lima (2014).

On the Table 1 - Actions of training and qualification of staff developed by Atlantica Hotels International, demonstrates the corporate actions carried out to train, qualify and train employees the Organization surveyed. In this way reveals that this is a tool that the organization directly or indirectly uses to contribute to the future of its employees, to the activity of receiving people, make them aware of the importance of education in their lives and improve the services to guests.

Accordingly, it seems that good examples in the context of openness and hospitality to guests are recorded positively by the staff and these reflect positively on the image of the organization, as an example, the case of guest who was surprised to receive, at the time of the check-out, a piece of the same cake he had complimented the day before during the breakfast (LIMA, 2014).

The hotel manager searched has more than 5,000 employees and represents 10 international brands divided into five segments, and after applying the questionnaire according to Lima (2014) it was elaborated Table 2 - Hotels managed by Atlantica Hotels International.

Table 2: Hotels managed by Atlantica Hotels International.

Quadro 2: Hotéis gerenciados pela Atlantica Hotels International.

\begin{tabular}{|l|l|}
\hline \multicolumn{1}{|c|}{ Segment } & \multicolumn{1}{c|}{ Flags } \\
\hline Budget & Go Inn \\
\hline Standard & Sleep Inn \\
\hline Midclass & Comfort \\
\hline Superior & Comfort Suites \\
& Quality \\
& Park Suites \\
& Park Inn by Radisson \\
\hline Luxury & Clarion \\
& Four Points by Sheraton \\
& Radisson \\
\hline
\end{tabular}

Source: Table made by the authors. Fonte: Quadro feito pelos autores. 
Analyzing the Table 2, it appears that the company researched seeks to attend different segments, considering from the most basic segment to the high standard of public, and then it was revealed that the arrangement of these data in a table form was made to better demonstrate each segment served by this company and their hotels.

According to Lima (2014) the hotel management share values are associated with ethics, integrity and professional honesty. In this terms, by looking at the website of this company it is possible to add that there is the proposal of responsible management and extensive attention to the wishes of its stakeholders, in the area directed to corporate responsibility lies the proposal for sustainable development and the pursuit for reducing social inequalities within the territorial limits of Brazil (ATLANTICA HOTELS INTERNATIONAL, 2015).

This happens because the company recognizes that through the development of its business, the hotel management, it is possible the existence of transgressions. Since sometimes there are guests and visitors who are unaware of the importance of actions in the context of environmental and social responsibility. Therefore, it was sought an organizational effort to prepare the staff to combat violence against children and adolescents (LIMA, 2014).

These actions sometimes also present, in order to maintain the good image of the company, in its interest groups, such as investors, customers, employees and suppliers and part of these initiatives are arranged on the organization's website and they are better defined as responsibility social, environmental responsibility and economic responsibility (ATLANTICA HOTELS INTERNATIONAL, 2015).

So, all of these actions tend to take larger proportions, since these aspects also extend to the guests and other stakeholders of these developments because, according to Lima (2014), successful actions have been developed to inform the company's intransigence in not admit minors of 18 who are not accompanied by legally recognized adults.

Through the strategic alliance with Childhood Brazil it is possible for guests and visitors of the hotels managed by Atlantica Hotels International to make directly donations to this institution at the reception. It is observed on the site of Childhood Brasil (2015) that there is a set of initiatives created in order to protect children and adolescents from sexual exploitation and this also uses the support of other sectors of society such as companies, social organizations and also tourist trade.

Among these social actions, it is highlighted the Great Programme "Grandes Obras, Programa Turismo, Programa Proteção em Rede" and the "Projeto Especial" (CHILDHOOD BRASIL, 2015). Consequently, we identify that this organization besides developing programs in the regional and national level, also seeks to support different projects that contribute to this cause.

So, according to Lima (2014) in the hotels environment managed by Atlantica Hotels International there is a Sustainability Committee which is 
made up of hotels employees at different levels: representatives of the technical departments, general managers and representatives of Childhood Brazil. To Lima (2014) they are the responsible ones for promoting the actions and define the guidelines of the network's sustainability programs.

From the perspective of the social and economic sustainability, to demonstrate the Organization's corporate ethics, the interview made with lime (2014) to elaborate the table 3-Actions of Sustainability developed in Social and economic spheres by the Atlantica Hotels International.

Table 3: sustainability actions developed in the Social and economic spheres by Atlantica Hotels International.

Quadro 3: ações de sustentabilidade desenvolvidas nas esferas social e econômica pela Atlantica Hotels International.

\begin{tabular}{|l|l|}
\hline \multicolumn{1}{|c|}{ Type of Sustainability } & \multicolumn{1}{c|}{ Examples } \\
\hline Social & $\begin{array}{l}\text { Combating Sexual exploitation of children } \\
\text { and adolescents }\end{array}$ \\
\hline Economical & $\begin{array}{l}\text { Offers products and services according to } \\
\text { the needs of the market; } \\
\text { Complies with aspects related to the } \\
\text { payment of taxes, labor and consumer rights; } \\
\text { Based on their business in aspects such as } \\
\text { transparency, honesty and fairness; }\end{array}$ \\
\hline
\end{tabular}

Source: Lima (2014). Fonte: Lima (2014).

On the Table 3 - sustainability actions developed in the Social and economic spheres by Atlantica Hotels International, hosting means that have the flag of the company researched seek to reconcile the routine activities of the Hotels with your development environment, that is, the progress of the cities where they are installed, in order to develop actions in the context of social and economic sustainability.

In the area meant to the environmental actions of Atlantica Hotels International, it is observed the requirement for hotel units develop actions associated with the use of visual communication totems in order to minimize the use of paper and plastic in the activities of the enterprise; encouraging the practice of selective collection of paper, plastic and glass; cooking oil collection; periodic cleaning of the air conditioners with biodegradable products; and separation of batteries and fluorescent lamps for recycling (ATLANTICA HOTELS INTERNACIONAL, 2015).

To reduce energy consumption the company seeks to install energy saving equipment in housing units; performing preventive maintenance on electrical panels and air conditioners; as well as provision of presence sensors in bathrooms and public areas; use of cold lamps in housing units and circulation areas of people; Timer available in saunas; timer installation and presence sensors in lamps; use of revolving doors and air curtains in airconditioned environments; and the use of elevators systems have reduced power consumption (ATLANTICA HOTELS INTERNACIONAL, 2015).

In order to reduce water consumption on the Atlantica Hotels International (2015) it is possible to see them encouraging the use of taps and 
urinal valves with automatic closing in public areas of bathrooms and changing rooms, there is also a six-monthly routine search for leaks in the environment of hotels done by a specialized company, the installation of flow reducers in sinks and douching, and finally, thermal insulation of pipes promotion. Through the data stated above has drawn up the table 4 - Environmental Sustainability Actions developed by Atlantica Hotels International.

Table 4: environmental sustainability Actions developed by Atlantica Hotels International. Quadro 4: Sustentabilidade ambiental Ações desenvolvidas pela Atlantica Hotels International.

\begin{tabular}{|c|c|}
\hline Activities & Examples \\
\hline Reduction of energy consumption & $\begin{array}{l}\text { Installation of energy-saving appliances in } \\
\text { housing units; } \\
\text { Performing preventive maintenance on } \\
\text { electrical panels, air conditioners; } \\
\text { Supply of presence sensors in bathrooms } \\
\text { and public areas; } \\
\text { Use of cold lamps in housing units and } \\
\text { areas of movement of persons; } \\
\text { Use of timers in saunas; } \\
\text { Installation of timers and presence sensors } \\
\text { in the lamps; } \\
\text { Use of revolving doors and curtains of air in } \\
\text { air-conditioned environments; } \\
\text { Elevator systems; }\end{array}$ \\
\hline Reduction of water consumption & $\begin{array}{l}\text { Encourage the use of taps with automatic } \\
\text { lock in public areas of bathrooms and } \\
\text { changing rooms; } \\
\text { Bi-annual search of leaks in the } \\
\text { environment of hotels conducted by } \\
\text { specialized firm; } \\
\text { Installing flow reducers on sinks and } \\
\text { showers; }\end{array}$ \\
\hline $\begin{array}{l}\text { Reduced consumption of other resources } \\
\text { such as paper, plastic, glass and cooking oil }\end{array}$ & $\begin{array}{l}\text { Use of totems of visual communication; } \\
\text { encouraging the practice of selective } \\
\text { collection of paper, plastic and } \\
\text { glass; Periodical collection of cooking oil; } \\
\text { Periodic cleaning of the air conditioners } \\
\text { with biodegradable products; } \\
\text { Separation of batteries and fluorescent } \\
\text { lamps for recycling; }\end{array}$ \\
\hline
\end{tabular}

Source: Atlantica Hotels International (2015). Fonte: Atlantica Hotels International (2015).

Upon the Table 4 - Environmental Sustainability Actions developed by Atlantica Hotels International, a set of actions performed in the apparent goal of reducing the waste produced, preserving the environment, reduce resource, also natural wastage, and save a variety of other resources that can be recycled, and minimize the reduction of emission of pollutants in nature.

So through these guidelines, this organization has established itself in Brazil as a reference model to consider seeking through the work of its managed hotels, traditional and innovative means to put good practices in the hotel industry. 


\section{Conclusion}

Through this study we sought to conduct an analysis of actions in the social and environmental context developed in lodging facilities, which used as a model of reference the hotels managed by Atlantica Hotels International, it has been shown then the importance of the performance and impacts from installing a mean of lodging in a tourist destination or region.

It has also been exposed through standards and adequate bibliography forms of seeking how to reconcile sustainable development and the hotel business, so it was demonstrated the importance of creating a Sustainability Committee and the case of ISO 15401, which deal specifically with the management of sustainability systems appropriate to the reality of lodging facilities.

Facing the problem and part of the research objectives, it was demonstrated through interviews with Mr. Paulo Lima (2014) and a research on the company's website that the actions developed in the environmental context by an organization of the hosting sector have to focus on its surroundings, either by encouraging local visitation and hospitality to welcome tourists, availability and qualification of enterprise developers through classroom courses and distance, encouragement to combat violence against children and adolescents, and finally by through actions in order to preserve the environment, or by adopting the best practices in operational routine of the enterprise and by the use of clean technologies and environmentally friendly.

By the hypotheses of the research, it appears that actions in order to inhibit sexual tourism are adopted by employees, as they are informed that the organization does not admit adults accompanied by under 18 unless they are legally recognized, this way even without statistical data observation, it is possible to see the impossibility of checking in in this organization and this permits to inhibit violence against children and adolescents around the venture.

Regarding the second case, it confirms that the actions in the social and environmental context reflect the good image of the company researched because the organization in the social area seeks to develop strategic alliances like the covenant made with Childhood Brazil, and want to promote positive values such as ethics, integrity and professional honesty, and in the environmental area in order to develop their routine activities actions aimed at minimizing the impacts of the activity.

On the other hand, the research also identifies that the actions in the context of improvement of social parameters and preservation of the characteristics related to the environment adds value to the offered service and retain guests and visitors. Finally, it is shown through the design and development of this study that it is possible to take actions in order to respect the environment and the local community in which the lodging facilities are, therefore, sometimes these companies may use strategic alliances or more time initiatives developed in the environment of the hosting means itself. 


\section{References}

ABBOTT, P.; WALLACE, C. Social Quality: A Way to Measure the Quality of Society. Soc Indic Res. 108:153-167, 2011.

ALUSI, A. et al. Sustainable Cities: Oxymoron or the Shape of the Future? Havard Business School, March, 2011.

APEC. Mission Statement. Disponível em: http://www.apec.org/AboutUs/About-APEC/Mission-Statement.aspx, acesso em 26 de junho de 2015.

APEC. Sustainable Development. Disponível em: http://www.apec.org/Home/Groups/Other-Groups/Sustainable-

Development.aspx, acesso em 26 de junho de 2015.

ASSOCIAÇÃO BRASILEIRA DE NORMAS TÉCNICAS. NBR 15401: Meios de Hospedagem - Sistema de Gestão da Sustentabilidade - Requisitos. Rio de Janeiro, 2006.

ATLANTICA HOTELS INTERNATIONAL. Responsabilidade Ambiental. Disponível em: http://www.atlanticahotels.com.br/responsabilidadeempresarial/responsabilidade-ambiental, acesso 15 de junho de 2015.

ATLANTICA HOTELS INTERNATIONAL. Responsabilidade Empresarial. Disponível em: http://atlanticahotels.com.br/responsabilidade-empresarial, acesso 17 de março de 2015.

ATLANTICA HOTELS INTERNATIONAL. Responsabilidade Social. Disponível em: http://www.atlanticahotels.com.br/responsabilidadeempresarial/responsabilidade-social, acesso 15 de junho de 2015.

BURGUI, M.B. Impactos paisajísticos de los neo-resorts y grandes villas hoteleras en el litoral. el caso de Cayo Santa María. (Villa Clara, Cuba). Cuadernos de Turismo, no 31, (2013); pp. 31-53.

CARTER, R.W. et al. Sustainable tourism and its use as a development strategy in Cambodia: a systematic literature review. Journal of Sustainable Tourism. Vol. 23, No. 5, 797_818, 2015.

CHILDHOOD BRASIL. Programas. Disponível em: http://www.childhood.org.br/programas, acesso 17 de março de 2015.

COMMISSION ON THE MEASUREMENT OF ECONOMIC PERFORMANCE AND SOCIAL PROGRESS. Welcome to the website of the Commission on the Measurement of Economic Performance and Social Progress. Disponível em: www.stiglitz-sen-fitoussi.fr/en/index.htm, acesso 09 de maio de 2015.

DIEGO, C.C.; PASCHOAL, C.A.; SALLES, M.R.R. Sustentabilidade ambiental e impactos na hotelaria. estudo de caso: Hotel Grand Hyatt São Paulo. TURyDES, Vol 4, № 9, 2011.

KOGA, E.S.; WADA, E.K. Análise dos Stakeholders e Gestão dos Meios de Hospedagem: estudo de casos múltiplos na Vila do Abraão, Ilha Grande, RJ. Turismo em análise, Vol. 24, n. 1, abril, 2013. 
LIMA, P. Pesquisa Hotéis - ações socioambientais. Dezembro de 2014. São Paulo. Questionário respondido a Anderson Soares Lopes.

MATOS, J.K.E.; COSTA, M.A.N. Sustentabilidade nos meios de hospedagem no Brasil: a norma NBR 15401:2006. Anais do CATS - Congresso de Arquitetura, Turismo e Sustentabilidade, Cataguases, MG, 2012.

MCCABE, S.; JOHNSON, S. The happiness factor in tourism: subjective wellbeing and social tourism. Annals of Tourism Research, Vol. 41, pp. 42-65, 2013.

MELLO, R.; NAIME, R.; HUPPFER, H.M. Avaliação sobre o uso de práticas de sustentabilidade na hotelaria - estudo de caso em hotéis de uma cidade do litoral norte do RS. Rev. Elet. em Gestão, Educação e Tecnologia Ambiental, Vol. 8, no 8, p. 1689-1699, set-dez, 2012.

MERCOSUL. Saiba mais sobre o MERCOSUL. Disponível em: http://www.mercosul.gov.br/index.php/saiba-mais-sobre-o-mercosul, acesso 26 de junho de 2015.

PERES JR., M.R.; REZENDE, D.C. Gestão da sustentabilidade no segmento hoteleiro: estudo dos meios de hospedagem de Monte Verde, MG. Caderno Virtual de Turismo, vol. 11, núm. 2, agosto, 2011, pp. 234-252. Universidade Federal do Rio de Janeiro, Río de Janeiro, Brazil.

SAULE JUNIOR, N. Introdução. In: ROMEIRO, P.S.; FROTA, H.B. (Orgs.). Megaprojetos de impacto urbano e ambiental: violação de direitos, resistência e possibilidades de defesa das comunidades impactadas. São Paulo: IBDU, 2015.

SOUZA, C.L.; SANTOS, J.G.; RAMALHO, A.M.C. Sistemas de Indicadores de Sustentabilidade: Um caminho para o Alcance do Turismo Sustentável. Anais do Seminário ANPTUR, São Paulo, 2012.

STOKES, D.E. O quadrante de Pasteur: a ciência básica e a inovação tecnológica. Campinas, SP: Editora UNICAMP, 2005.

WWF Brazil. O que é desenvolvimento sustentável? Disponível em: http://www.wwf.org.br/natureza brasileira/questoes ambientais/desenvolvime nto sustentavel/, acesso em 08 de fevereiro de 2014.

ZIONI, F. Ciências sociais e meio ambiente. In: PHILIPPI JR., A.; PELICIONI, M.C.F. (editores). Educação ambiental e sustentabilidade. Barueri, SP: Manole, 2005. 
Anderson Soares Lopes: Universidade Anhembi Morumbi, São Paulo, SP, Brasil.

E-mail: aslturjp@yahoo.com.br

Link para o currículo Lattes: http://lattes.cnpq.br/3300579366589040

Paulo Santos de Almeida: Escola de Artes, Ciências e Humanidades da Universidade de São Paulo, São Paulo, SP, Brasil.

E-mail: psalmeida@usp.br

Link para o currículo Lattes: http://lattes.cnpq.br/9769033547975455

Data de submissão: 10 de maio de 2018

Data de recebimento de correções: 03 de agosto de 2018

Data do aceite: 03 de agosto de 2018

Avaliado anonimamente 